P-ISSN: 2774-4574; E-ISSN: 2774-4582

TRILOGI, 2(3), September-Desember 2021 (239-251)

@2021 Lembaga Penerbitan, Penelitian,

dan Pengabdian kepada Masyarakat (LP3M)

Universitas Nurul Jadid Paiton Probolinggo

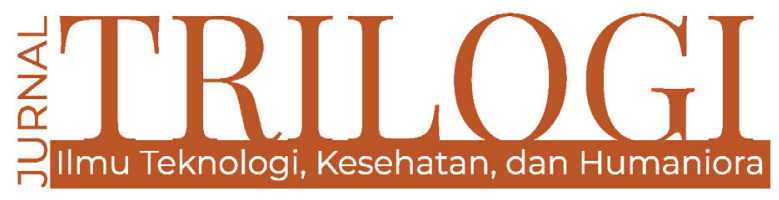

\title{
PREDICTION OF PATIENTS' ILLNESS BASED ON AVERAGE TEMPERATURE AND RAINFALL IN AZ-ZAINIYAH CLINIC USING BACKPROPAGATION METHOD
}

\author{
M Noer Fadli Hidayat \\ Universitas Nurul Jadid, Probolinggo \\ fadli@unuja.ac.id
}

\begin{abstract}
Abstrak
The purpose of this study is to predict the type of disease in students based on the average temperature and rainfall at the Az-Zainiyah clinic using the backpropagation method. With this research, we hope that the prediction/estimation process on the type of patient's disease using the backpropagation artificial neural network method provides a solution with precise and accurate prediction results based on data on many patients, average temperature, and previous rainfall. This research is carried out through a process of predicting the type of disease by collecting time-series data from patient visit reports. The raw data obtained are examined for completeness and quality of the data. Then, the data was analyzed and applied to an artificial neural network method to predict the type of patient's disease based on many patients, average temperature, and rainfall. Furthermore, the artificial neural network will be optimized by the backpropagation algorithm. From this study, we find that the percentage of precision obtained in the experimental type of pharyngitis/sore throat disease in November 2020 with an average precision percentage is $68.92 \%$, the best precision percentage is $90.25 \%$, and the worst precision percentage $47.59 \%$. In December 2020 , the average precision percentage is $41.46 \%$, with the best precision percentage being $65.55 \%$, and the worst precision percentage $4.92 \%$. In the type of dermatitis/itching disease in November 2020, the best precision percentage is $98.81 \%$, the average precision percentage is $68.31 \%$, and the worst precision percentage is $-21.57 \%$. For December 2020, the average precision percentage is $-63.27 \%$, the best precision percentage is $48.37 \%$, and the worst precision percentage is $-183.85 \%$.
\end{abstract}

Katakunci: prediction; disease; backpropagation; 


\section{Pendahuluan}

The Disease can be interpreted as a condition when there is a disturbance in the form or function of one part of the body that causes the body to be unable to work normally (Basariyadi, 2017). Climate change can also have direct or indirect effects on human health. The direct effects on human health are the effects of extreme cold and extreme heat (Ernyasih et al., 2018). High temperature accompanied by low humidity causes the body to easily dehydrate. Indirect effects are related to infectious diseases which are caused by air pollution and erratic weather (Surakusumah, 2011).

The human body is very susceptible to various types of diseases, both mild and chronic diseases. Unhealthy lifestyles and unfavorable environmental factors cause immunity decreasing which results in the outbreak of a disease. Environmental factors are all external factors affecting an individual who can be the form of social environment, biological environment, and physical environment. One of the physical environments, namely climate, needs to be watched out for because disease transmission will increase with climate change (Bustan, 1997). Part of the physical environmental conditions is air humidity and rainfall, one of the elements that affect the climate is rainfall (Paramita and Mukono, 2018).

In Nurul Jadid Islamic Boarding School, the student health service is carried out by Azzainiyah Clinic. It also provides health counseling services, health consulting services, medical services, and other health services. Azzainiyah is a health clinic founded by the Nurul Jadid Islamic Boarding School located in Tanjung Lor Hamlet, Karanganyar, Paiton, Probolinggo Regency. In addition to providing health services to students, this clinic is also a social institution that accommodates pesantren services in the social and community fields. Az-Zainiyah Clinic is for students, teachers, lecturers, employees, and the general public around them.

In carrying out health services, the provision of medicines is not based on the number of patients suffering from a type of disease whose grade may increase in the coming months yet, which is influenced by several factors, namely average temperature and rainfall. Thus, resulting in minimal drug stock availability, not under the needs based on the type of patient's illness, and even empty drug stocks. It will be a big problem for general patients and students in the Nurul Jadid area. Therefore, we need a method or method to predict the type of patient's disease based on the number of patients, the average temperature, and rainfall by looking at the previous data. One way to predict is to use an artificial neural network.

An artificial Neural Network (ANN) is a simulated representation of the human brain which always tries to simulate the learning process in the human brain. The term artificial here is used because this neural network is implemented using a computer program that can complete several calculation processes during the learning process (Kusumadewi, 2003). The main advantage of the ANN system is the ability to "learn" from the examples given. Backpropagation is a supervised learning algorithm and is usually used by multilayer perceptrons to change the weights connected to neurons in the hidden layer. Backpropagation is a type of controlled training (supervised) that uses a weight adjustment pattern to achieve a minimum error value between the predicted output and the exact output. (F. Suhandi, 2009).

The artificial neural network is a branch of AI (Artificial Intelligence), which is a simulated representation of the human brain that always tries to simulate the learning process in the human brain. This artificial term is implemented using a computer program that can complete some calculation processes during the learning process (Suyanto, 2011). The backpropagation method is one of the methods used in learning from artificial neural network algorithms (Patel, 2013). The backpropagation method has a high level of accuracy because the training process is carried out repeatedly, so it produces a value that has a very small error (Anshari and Muniar, 2016). The backpropagation learning method is applied widely for solving a problem related to identification, prediction, and pattern recognition.

We can use the backpropagation method in medical analysis, such as identifying a disease having symptoms biased between one type and another. It has been proved in the journal "Application of artificial neural networks to predict respiratory tract diseases with the backpropagation method" by Novi Indah Pradasari, F.Trias Pontia W, and Dedi Triyanto (2013). In their journal, they used the backpropagation method to predict respiratory tract diseases based on disease symptoms arranged into 12 input variables. The system's output target is in the form of respiratory tract diseases identified by the system. The 
system has disease limits that can be identified. Those are Asthma, ARI, Pneumonia, Bronchitis, Sinusitis, and Tuberculosis. This study concluded that we could use the backpropagation method to predict respiratory tract disease with an accuracy of $91.66 \%$ obtained from training 96 data and testing 24 data using two hidden layers, a target error of 0.0001 , and a learning rate of 0.1 .

Miss Ankeeta R. Patel and Maulin M. Joshi (2013) conducted research using backpropagation to diagnose heart disease using data from Cleveland. The results of the tests carried out with Cleveland data obtained MSE 0.0013 and the success reached $100 \%$. So this study shows that neural networks are quite good for use in the diagnosis of heart disease. In another study, the backpropagation method was also used to predict heart disease. The result of this research is that the backpropagation algorithm can predict heart disease with more accurate results, namely 91.45\% accuracy (Rifai, 2013).

Furthermore, the research conducted by Dewi \& Muslikh (2013) was about comparing the accuracy of backpropagation neural networks with the Adaptive Neuro-Fuzzy Inference System (ANFIS) for predicting the weather. In backpropagation, there are 3 layers and in the hidden layer, the number of hidden neurons can be changed so that an optimal network can be generated. However, in ANFIS there are 5 layers at the initial stage using the K-Mean Clustering method to produce premise and consequent parameters that are useful during learning. From the results of the tests carried out, it was found that the backpropagation method obtained a smaller Root Mean Square Error (RMSE) value and greater accuracy than the ANFIS method.

According to the description and the research conducted, the backpropagation method can be used as a support for predicting the type of patient's disease based on the number of patients, average temperature, and rainfall at the Az-Zainiyah clinic.

Based on this description, the purpose of this study is to predict the type of disease in students based on the average temperature and rainfall at the Az-Zainiyah clinic using the backpropagation method. With this research, we expect that the prediction/estimation process on the type of patient's disease using the backpropagation artificial neural network method provides a solution with precise and accurate prediction results based on the number of patients, average temperature, and previous rainfall.

\section{Metode}

To achieve the expected goals in this study, we make a research design in the process of predicting the type of patient's disease based on data on the number of patients, average temperature, and rainfall at the Az-Zainiyah Clinic, which we can see in the following figure.

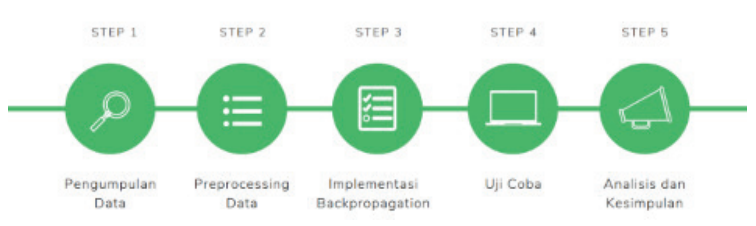

The steps carried out according to the research design based on Figure 3.1 to predict the type of patient's disease at the Azzziniyah Clinic using the backpropagation method we can explain in more detail as follows.

1. Data Collecting

We collect Data through an observation process at the Azzainiyah Clinic. The activities carried out in this observation are collecting time-series data on patient visit reports, such as a list of names and the highest total number of diseases every week. We also record steps from weekly frequency data to monthly frequency data. The data used in this study is data on the type of patient's disease. Those are pharyngitis/sore throat and dermatitis/itching from January 2020 until December 2020.

\section{2. $\quad$ Preprocessing Data}

At this stage, we combine and check the raw data obtained for the completeness and quality of the data. We check whether the data is ready and can be used to develop models and make forecasts/predictions using the data. Furthermore, we will correct the data if there is empty data or noise. We can improve the data using old data or forecasting empty data in advance using the moving average method or averaging the previous data. Thus, we can say the data is valid for making models and forecasting.

Then, we process the data according to research needs. This data is categorized to facilitate the process of testing the method. After it is ready to use, the next step is developing an artificial neural network (ANN) model. The development of this ANN model can be started by categorizing the parameters into inputs and outputs. We classify the input 
data based on predetermined parameters, these are the number of patients last month, the average temperature last month, the average temperature next month, last month's rainfall, and rainfall next month. Then these parameters produce an output variable, namely the target of "many patients next month". We use all of those parameters as input for the training and testing process which will result in the precision value of the model and the optimization that will be applied. At this stage, the data obtained from the results of data collection is $80 \%$ for training and $20 \%$ for testing.

Furthermore, the value of the input variable from each of the testing and training data is normalized. We normalize the data to adjust the value of the data to the range of activation functions used in the network. The process of the data normalizing is done automatically by using the toolbox in MATLAB, that is mapstd. So that values that already have a fixed range can be used in the next stage.

3. Backpropagation Implementation

At the implementation stage, the analyzed data are grouped based on which variables are related to. After we analyze the data, we then applied to the proposed method, namely the artificial neural network method to predict the type of patient's disease based on the number of patients, the average temperature, and rainfall. Furthermore, the artificial neural network will be optimized with the backpropagation algorithm and implemented in MATLAB.

Next, we determine the backpropagation architecture consisting of the input, hidden, and output layer as well as the parameters used in the model training process consisting of the learning rate, momentum, maximum epoch, and activation function. The input layer contains five units representing parameters. There are 3 layers for last month and 2 layers for next month. The layers for last month are the number of patients, average temperature, and rainfall. For another month, the layers are average temperature and rainfall. The output layer consists of one unit which will result in "many patients next month".

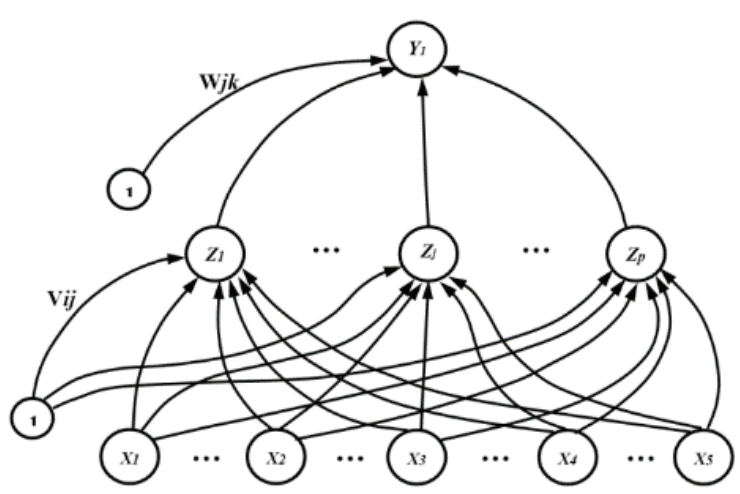

Gambar 1 : Arsitektur Jaringan Backpropagation

4. Result Testing

Testing the prediction results is the most critical stage in this research. At this stage, we verify the proposed model to see the results in the form of rules that will be used in decision support, to find out and determine whether a backpropagation neural network method has been successfully developed or not. Then evaluate and validate the results to determine the level of precision of the model. We test the preciseness of data testing using the following formula.

100\% - [ | Data Aktual (Target) - Hasil Peramalan (Prediksi) | $\times 100]$ Data Aktual (Target)

5. Analysis and Conclusion

From the test results, we can draw the analysis and conclusions about the level of precision of the backpropagation artificial neural network (ANN) method in predicting the type of patient's disease based on the number of patients, average temperature, and rainfall at the Az-Zainiyah clinic.

\section{Discussion}

\subsection{Disease}

The disease is the failure of the adaptation process of a living being to react appropriately to stimuli or pressures so that disturbances in the function or morphology of organs or body systems appear (Basariyadi, 2017).

\subsection{Air Temperature and Rainfall}

Air temperature is the level or degree of heat from the activity of molecules in the atmosphere expressed on the Celsius scale. The air temperature of each area is different. It is influenced by several factors, namely the angle 
of incidence of sunlight, the altitude of the place, wind and ocean currents, duration of irradiation, and clouds (Wulandari, 2011). Usually, the measurement of temperature or air temperature is expressed in Celsius (C), Reaumur ( $R$ ), and Fahrenheit $(F)$ scales. The air temperature in the open environment is not the same as the air in the building, neither is the ambient temperature such as in the dry and the wet fields. Measurement of air temperature only obtains one value which states the average value of the atmosphere. There are two environmental air temperature measurement scales that are often used, namely the Fahrenheit scale used in the UK and the Celsius scale used by most countries in the world (Heriyani, 2019). In general, the maximum temperature occurs afternoon, usually between 12.00 to 14.00 and the minimum temperature occurs at 06.00 local times and around sunrise (Tjasyono, 2004).

Average daily air temperature is defined as the average of observations for 4 hours (one day) conducted every hour. The average daily air temperature can be calculated by adding up the maximum and minimum temperatures and then dividing by two. The average monthly temperature is the sum of the daily temperatures in a month divided by the number of days in that month (Tjasyono, 2004).

Rainfall is the height of rainwater that collects in a flat place, does not evaporate, does not seep, and does not flow. Rainfall of 1 (one) millimeter means that in an area of one square meter on a flat place, one millimeter of water can be accommodated or one liter of water can be accommodated within a certain period (Darmaga Climatology Station Bogor, 2012). Rainfall that falls in the territory of Indonesia is influenced by factors such as the shape of the terrain or topography, the direction of the terrain, the direction of the wind parallel to the coastline, and the distance the wind travels over flat terrain (Regariana, 2005).

\subsection{Backpropagation}

Backpropagation is one of the learning algorithms used for networks with multilayer networks or networks of many layers to change the weights connected to the neurons in the hidden layer. In the backpropagation method, there are two calculation paths. Those are forward propagation and backward propagation (Wadi, 2020). This network model is often used for the process of prediction, recognition, and forecasting (Dewi \& Muslikh, 2013).

In a backpropagation network, each unit in the input layer corresponds to every unit in the hidden layer. Each unit in the hidden layer is related to the unit in the output layer. This network consists of many layers (multilayer network). When this network is given an input pattern as a training pattern, then the pattern goes to the hidden layer units to be further forwarded to the units in the output layer. Then the output layer units will respond as the output of the artificial neural network. When the output is not as expected, the output will be propagated backward in the hidden layer and then from the hidden layer to the input layer.

There are three (3) basic backpropagation training algorithms, namely: backpropagation architecture, backpropagation activation function, and backpropagation basic training.

1. Backpropagation Architecture

The backpropagation network consists of several layers, those are an input layer with n neurons (plus a bias), a hidden layer consisting of $p$ neurons (plus a bias), and $m$ outputs where each neuron in a layer is fully connected to each. Neurons in the layer above or below it, except in the bias, are only fully connected to the neurons of the layer above (Fausett, 1994).

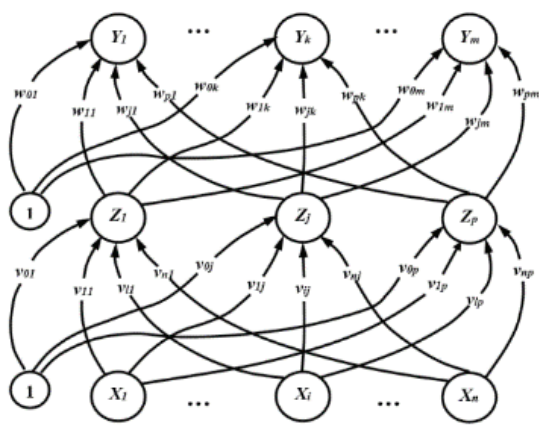

Gambar 2: Arsitektur Backpropagation

2. Function of Backpropagation Activation

a. The binary sigmoid function is an activation function that is often used in backpropagation activation whose range is $(0,1)$.

$$
\begin{aligned}
& f_{1}(x)=\frac{1}{1+\mathrm{e}-{ }^{\mathrm{x}}} \text { dengan turunan } \\
& f_{1^{\prime}}(x)=f_{1}(x)\left[1-f_{1}(x)\right]
\end{aligned}
$$


We illustrate the binary sigmoid function in the following figure.

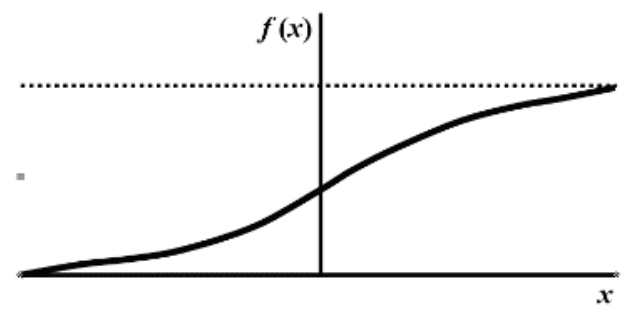

Gambar 3 : Binary Sigmoid Function

b. The bipolar binary sigmoid function is a function whose form is similar to the binary sigmoid function, but with a range $(-1,1)$.

$f_{2}(x)=\frac{2}{1+\mathrm{e}-{ }^{\mathrm{x}}}-1$ with the derivative

$f_{2^{\prime}}(x)=\frac{1}{2}\left[1-f_{2}(x)\right]\left[1-f_{2}(x)\right]$

The bipolar binary sigmoid function can be seen in the following figure.

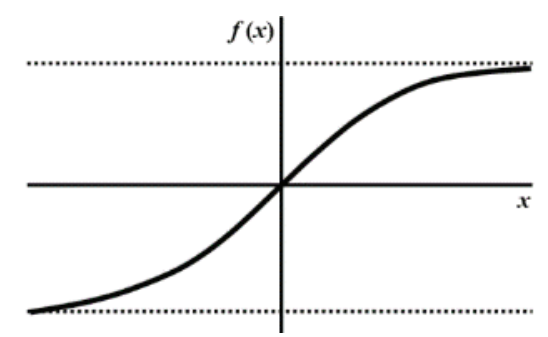

Gambar 4 : Bipolar Binary Sigmoid Function

3. Backpropagation Training

One of the activation functions defined in the previous section can be used in a given standard backpropagation algorithm. The shape of the data (especially the target value) is a critical factor in selecting the appropriate function. Another suitable activation function considered in Figure 2.3 is the binary sigmoid function. Note that due to the simple relationship between the value of the function and its derivative, no additional evaluation of the exponential is required to calculate the derivative required during the backpropagation phase of the algorithm (Fausett, 1994).

In the backpropagation training algorithm, there are three stages. The first stage is the feedforward propagation stage, namely, when the network calculates the output data, the second stage is the backward propagation stage (backpropagation) if there is an error (difference between the desired output target and the output value obtained), and the third stage is weight modification to reduce network-generated errors.

The backpropagation training algorithm is as follows:

Step 0: Initialize all weights with small random numbers.

Step 1: If the termination condition does not hold, perform steps 2-9.

Step 2: For each pair of training data, perform steps 3-8.

\section{$1^{\text {st }}$ Stage: Feedforward Propagation.}

Step 3: Each input layer ( $\mathrm{Xi}, \mathrm{i}=1, \ldots, \mathrm{n})$ receives the input signal $x i$ and forwards it to the hidden layer.

Step 4: Count all outputs in the hidden layer $\left(Z_{j}, j=1, \ldots, p\right)$,

$z_{i n_{j}}=v_{0 j} \sum_{i=1}^{n} x_{i} v_{i j}$

Apply the activation function to calculate the output signal,

$z_{j}=f\left(z_{-} i n_{j}\right)$,

Send the signal to all output layer.

Step 5: Calculate all output in output layer $\left(Y_{\mathrm{k}} k=1, \ldots, m\right)$,

$y_{-} i n_{k}=w_{0 k}+\sum_{j=1}^{p} z_{j} w_{j k}$

Apply the activation function to calculate the output signal,

$Y k=f\left(y_{-} i n_{\mathrm{k}}\right)$.

\section{$2^{\text {nd }}$ Stage: BACKPROPAGATION}

Step 6: Calculate the factor $\delta$ on the output layer based on error in every output layer $\left(Y_{k}, k=1, \ldots\right)$,

$\delta_{k}=\left(t_{k}-y_{k}\right) f^{\prime}\left(y_{-}\right.$in $\left._{k}\right)$,

$\delta_{k}$ is the error unit which can be used in the change of layer weight below (step 7).

Calculate the unit of weight change $w_{j \mathrm{k}}$ (which will be used for changing the weight $w_{\mathrm{jk}}$ ) with 
the acceleration rate $\alpha$,

$\Delta w_{\mathrm{jk}}=\alpha \delta_{k} z_{j}$

Calculate the bias change (which will be used for change the weight $\left.w_{0 \mathrm{k}}\right)$,

$\Delta w_{0 \mathrm{k}}=\alpha \delta_{k^{\prime}}$

Send $\delta_{k}$ to the layer below it.

Step 7: Calculate the factor $\delta$ on the hidden layer based on the error in every hidden layer unit $\left(Z_{j,} j=1, \ldots,\right)$,

The factor $\delta$ hidden layer is:

$\delta_{j}=\delta_{-}$in $_{j} f^{\prime}\left(z_{-}\right.$in $\left._{j}\right)$,

Compute the weight change $v_{\mathrm{ij}}$ (which will be used for change the weight $v_{\mathrm{ij}}$ later),

$\Delta v_{\mathrm{ij}}=\alpha \delta_{j} x_{i^{\prime}}$

\section{$3^{\text {rd }}$ Stage: Weight Change.}

Step 8: Calculate all weight change.

The change of line weight which leads to the output layer

$w_{\mathrm{jk}}($ baru $)=w_{\mathrm{jk}}(\operatorname{lama})+$

$\Delta w_{\mathrm{jk}^{\prime}}\left(Y_{\mathrm{k}^{\prime}}, k=1, \ldots, ; j=0, \ldots, p\right)$.

The change of line weight which leads to hidden layer,

$v_{\mathrm{ij}}($ baru $)=v_{\mathrm{ij}}($ lama $)+$

$\Delta v_{\mathrm{ij}}\left(Z_{\mathrm{j}}, j=1, \ldots, p ; i=0, \ldots, n\right)$.

Step 9: The training process is finished.

After the training is complete, the network can be used for pattern recognition. In this case, only forward propagation (steps 4 and 5 ) is to determine the network output.

\subsection{Data Presentation}

The results of data collection are conducted at the Az-Zainiyah clinic and the Meteorology, Climatology and Geophysics Agency (BMKG) Malang Climatology Station. In the observations, researchers obtained time series data on patient visit reports from January to December 2020. In the reports obtained, there are five lists of the most common types of the disease every week. Then the researcher unites and groups the weekly frequency data into monthly frequency data based on which variables are related to each other. From the monthly data that has been put together and grouped, there are various types of diseases got. We only take two types of diseases that we use as parameters in the study as needed, namely pharyngitis/sore throat, and dermatitis/itching.

In the results from BMKG Malang Climatology Station, we get time-series data for daily climate reports. Then, from the daily frequency data, we process it into monthly frequency data by calculating the average results from the daily frequency data. The data needed by researchers are the parameters of the average temperature and rainfall. The results of data collection can be seen in Table 1.

Table 1: Data on Number of Patients, Average Temperature, and Rainfall from January to December 2020

\begin{tabular}{|l|c|c|c|c|}
\hline \multicolumn{1}{|c|}{ Bulan-Tahun } & $\begin{array}{c}\text { Faringitis } \\
\text { (Radang } \\
\text { Tenggorokan) }\end{array}$ & $\begin{array}{c}\text { Dermatitis } \\
(\text { Gatal- } \\
\text { Gatal) }\end{array}$ & $\begin{array}{c}\text { Temperatur } \\
\text { rata-rata } \\
\left({ }^{\circ} \mathrm{C}\right)\end{array}$ & $\begin{array}{c}\text { Curah } \\
\text { hujan } \\
(\mathrm{mm})\end{array}$ \\
\hline Januari 2020 & 70 & 39 & 23,8 & 310,9 \\
\hline Februari 2020 & 25 & 40 & 23,7 & 642,9 \\
\hline Maret 2020 & 69 & 69 & 24,0 & 619,8 \\
\hline April 2020 & 66 & 21 & 24,8 & 595.2 \\
\hline Mei 2020 & 34 & 35 & 24,1 & 0,6 \\
\hline Juni 2020 & 21 & 2 & 23,2 & 1,9 \\
\hline Juli 2020 & 47 & 42 & 21,9 & 0,3 \\
\hline Agustus 2020 & 24 & 59 & 22,2 & 0,0 \\
\hline September 2020 & 55 & 52 & 23,8 & 0,1 \\
\hline Oktober 2020 & 29 & 21 & 25,2 & 0,2 \\
\hline November 2020 & 37 & 27 & 25,0 & 1196,1 \\
\hline Desember 2020 & 26 & 19 & 24,1 & 309,8 \\
\hline
\end{tabular}

\subsection{Data Preprocessing}

The data obtained is then processed according to research needs. This data is categorized to facilitate the process of testing the backpropagation neural network (ANN) method to predict the type of patient's disease based on the number of patients, average temperature, and rainfall. The data in Table 4.1 are grouped based on which parameters are related. The parameters are the number of patients last month (pharyngitis/sore throat, and dermatitis/itching), the average temperature last month, the average temperature next month, rainfall last month, rainfall next month. These parameters become input variables which are described as follows.

$x 1=$ The number of Last Month's Patients (Pharyngitis/Sore Throat, and Dermatitis/Itching)

$x 2=$ Last Month's Average Temperature

$x 3=$ Next Month's Average Temperature

$x 4=$ Last Month's Rainfall

$x 5=$ Next Month's Rainfall Next, the parameters deliver the following output variable or targets. 
$t 1=$ The Number of Patients Next Month (Pharyngitis/Sore Throat, and Dermatitis/Itching).

We use all of these parameters as input for the training and testing process. Next, determine the dataset that we will use for $80 \%$ training data and $20 \%$ testing data.

Table 2 below shows the datasets preprocessed or grouped based on the parameters that we determined in the study.

Tabel 2 Grouping Results Based on Input and Output Parameters

\begin{tabular}{|c|c|c|c|c|c|c|}
\hline Penyakit & $\begin{array}{c}\text { Banyak } \\
\text { Pasien }\end{array}$ & \multicolumn{2}{|c|}{ Temperatur Rata-Rata } & \multicolumn{2}{c|}{ Curah Hujan } & $\begin{array}{c}\text { Target } \\
\text { Penyakit }\end{array}$ \\
\hline $\begin{array}{c}\text { Jenis } \\
\text { Penyakit }\end{array}$ & $\begin{array}{c}\text { Bulan } \\
\text { Kemarin } \\
\text { (Januari } \\
2020)\end{array}$ & $\begin{array}{c}\text { Bulan } \\
\text { Kemarin } \\
\text { (Januari }\end{array}$ & $\begin{array}{c}\text { Bulan } \\
\text { Depan } \\
\text { (Februari }\end{array}$ & $\begin{array}{c}\text { Bulan } \\
\text { Kemarin } \\
\text { (Januari }\end{array}$ & $\begin{array}{c}\text { Bulan } \\
\text { Depan } \\
\text { (Februari }\end{array}$ & $\begin{array}{c}\text { Bulan } \\
\text { Depan } \\
\text { (Februari }\end{array}$ \\
\hline Faringitis & 70 & 23,8 & $230)$ & $2020)$ & $2020)$ & $2020)$ \\
\hline Dermatitis & 39 & 23,8 & 23,7 & 310,9 & 642,9 & 25 \\
\hline
\end{tabular}

Furthermore, the value of the input variable is normalized automatically by using the toolbox in MATLAB, namely mapstd. So that values that already have a fixed range can be used in the next stage. All training data and testing data will be normalized using the standard deviation. Normalization is applied so that the values generated from the previous process are uniform. The following is an implementation in MATLAB through the coding process.

[Hasil_normalisasi,ps] = mapstd (data_input);

Sample data before normalization is shown in Table 3. Table 4 shows the results of the normalization of training data in Table 3, while testing data before and after normalization is shown in Table 5.

Table 3 Training Data Before Normalization Against Pharyngitis In January to October 2020

\begin{tabular}{|c|c|c|c|c|}
\hline $\begin{array}{c}\text { Banyak } \\
\text { Pasien }\end{array}$ & \multicolumn{2}{|c|}{ Temperatur Rata-Rata } & \multicolumn{2}{|c|}{ Curah Hujan } \\
\hline $\begin{array}{c}\text { Bulan } \\
\text { Kemarin }\end{array}$ & $\begin{array}{c}\text { Bulan } \\
\text { Kemarin }\end{array}$ & $\begin{array}{c}\text { Bulan } \\
\text { Depan }\end{array}$ & $\begin{array}{c}\text { Bulan } \\
\text { Kemarin }\end{array}$ & Bulan Depan \\
\hline 70 & 23,8 & 23,7 & 310,9 & 642,9 \\
\hline 25 & 23,7 & 24,0 & 642,9 & 619,8 \\
\hline 69 & 24,0 & 24,8 & 619,8 & 595,2 \\
\hline 66 & 24,8 & 24,1 & 595,2 & 0,6 \\
\hline 34 & 24,1 & 23,2 & 0,6 & 1,9 \\
\hline 21 & 23,2 & 21,9 & 1,9 & 0,3 \\
\hline 47 & 21,9 & 22,2 & 0,3 & 0,0 \\
\hline 24 & 22,2 & 23,8 & 0,0 & 0,1 \\
\hline 55 & 23,8 & 25,2 & 0,1 & 0,2 \\
\hline
\end{tabular}

Table 4 Results of Training Data After Normalization of Pharyngitis Disease in January to October 2020

\begin{tabular}{|c|c|c|c|c|}
\hline $\begin{array}{l}\text { Banyak } \\
\text { Pasien }\end{array}$ & \multicolumn{2}{|c|}{ Temperatur Rata-Rata } & \multicolumn{2}{|c|}{ Curah Hujan } \\
\hline $\begin{array}{c}\text { Bulan } \\
\text { Kemarin }\end{array}$ & $\begin{array}{l}\text { Bulan } \\
\text { Kemarin }\end{array}$ & $\begin{array}{l}\text { Bulan } \\
\text { Depan }\end{array}$ & $\begin{array}{c}\text { Bulan } \\
\text { Kemarin }\end{array}$ & $\begin{array}{l}\text { Bulan } \\
\text { Depan }\end{array}$ \\
\hline-0.5390 & -0.7117 & -0.7121 & 0.3611 & 1.6017 \\
\hline-0.7278 & -0.7317 & -0.7307 & 1.1298 & 1.0604 \\
\hline-0.6335 & -0.7776 & -0.7752 & 1.1326 & 1.0537 \\
\hline-0.2994 & -0.4614 & -0.4640 & 1.7812 & -0.5565 \\
\hline 1.1658 & 0.4990 & 0.4331 & -1.0917 & -1.0062 \\
\hline 0.6382 & 0.8259 & 0.7195 & -1.0245 & -1.1591 \\
\hline 1.4780 & 0.1879 & 0.1997 & -0.9246 & -0.9411 \\
\hline 0.7830 & 0.6391 & 0.7655 & -1.0981 & -1.0894 \\
\hline 1.5087 & 0.1293 & 0.1901 & -0.9163 & -0.9118 \\
\hline
\end{tabular}

Table 5 Testing Data Before and After Normalization of Pharyngitis Disease in November 2020

\begin{tabular}{|c|c|c|c|c|}
\hline \multicolumn{5}{|c|}{ Data Sebelum Normalisasi } \\
\hline $\begin{array}{l}\text { Banyak } \\
\text { Pasien }\end{array}$ & \multicolumn{2}{|c|}{ Temperatur Rata-Rata } & \multicolumn{2}{|c|}{ Curah Hujan } \\
\hline $\begin{array}{c}\text { Bulan } \\
\text { Kemarin }\end{array}$ & $\begin{array}{c}\text { Bulan } \\
\text { Kemarin }\end{array}$ & $\begin{array}{l}\text { Bulan } \\
\text { Depan }\end{array}$ & $\begin{array}{c}\text { Bulan } \\
\text { Kemarin }\end{array}$ & $\begin{array}{l}\text { Bulan } \\
\text { Depan }\end{array}$ \\
\hline 29 & 25.2 & 25.0 & 0.2 & 1196.1 \\
\hline \multicolumn{5}{|c|}{ Data Sesudah Normalisasi } \\
\hline $\begin{array}{l}\text { Banyak } \\
\text { Pasien }\end{array}$ & \multicolumn{2}{|c|}{ Temperatur Rata-Rata } & \multicolumn{2}{|c|}{ Curah Hujan } \\
\hline $\begin{array}{c}\text { Bulan } \\
\text { Kemarin }\end{array}$ & $\begin{array}{l}\text { Bulan } \\
\text { Kemarin }\end{array}$ & $\begin{array}{l}\text { Bulan } \\
\text { Depan }\end{array}$ & $\begin{array}{c}\text { Bulan } \\
\text { Kemarin }\end{array}$ & $\begin{array}{l}\text { Bulan } \\
\text { Depan }\end{array}$ \\
\hline-0.4297 & -0.4370 & -0.4373 & -0.4844 & 1.7884 \\
\hline
\end{tabular}

\subsection{Implementation on Backpropagation}

At the implementation stage of the method based on the research design in the previous chapter, after normalizing the input data is to create a network that we use in the training process. Next, determine the backpropagation architecture to get an artificial neural network (ANN) model with good performance in forecasting/predicting. In this study, the backpropagation architecture used is 5-13-1 with 5 (five) parameters as variables that become signals as inputs, 13 (thirteen) hidden layers, and 1 (one) parameter that produces output signal variables. (output) can be seen in Figure 4.1.

The next is to determine and assign values to the parameters that affect the model training process. The parameters used to consist of the learning rate (Ir), momentum (mc), maximum iteration, and activation function which uses the logsig activation function in the first layer and the second function is linear (purelin) and the activation function used in the training process uses traingdx, which combines learning rate or learning rate (Ir) and momentum (mc) during the training process. It can be seen in the syntax used to build the ANN and the parameters that affect it. 

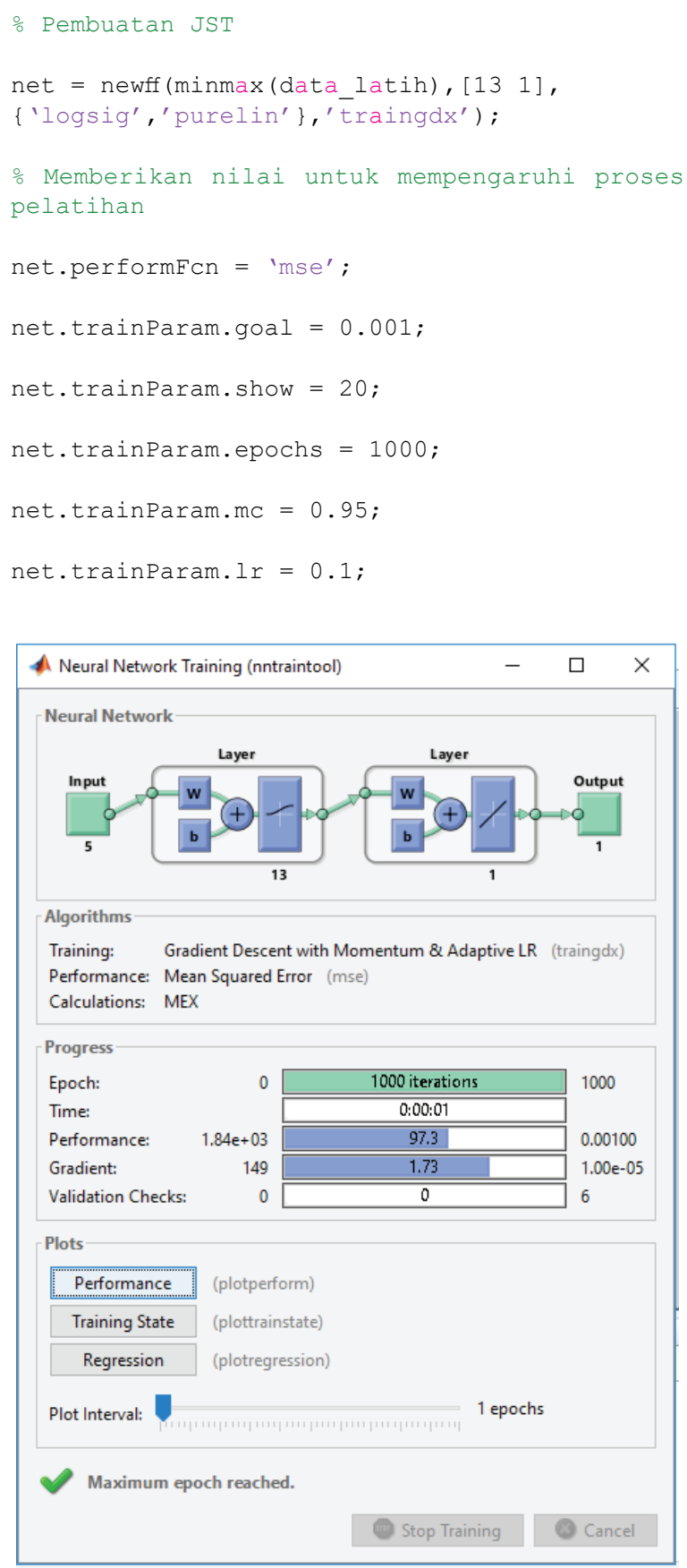

Figure 5 Implementation of Backpropagation Architecture

The results of the backpropagation implementation tested to predict the type of patient's disease, such as taking an example of pharyngitis based on many patients, average temperature, and rainfall illustrated in graphical form can be seen in Figure 4.4. This graph shows the target and predicted ANN results from the backpropagation architecture formed and implemented into the MATLAB R2014a application. This graph is generated in Figures 6 and 7 which are tested during one trial to predict pharyngitis in November and December 2020. The target for pharyngitis in November 2020 was 37 people with a predicted result of 25.92, which can be seen in Figure 4.2, and the target in December 2020 is 26 people with a prediction result of 48.08 in Figure 7 .

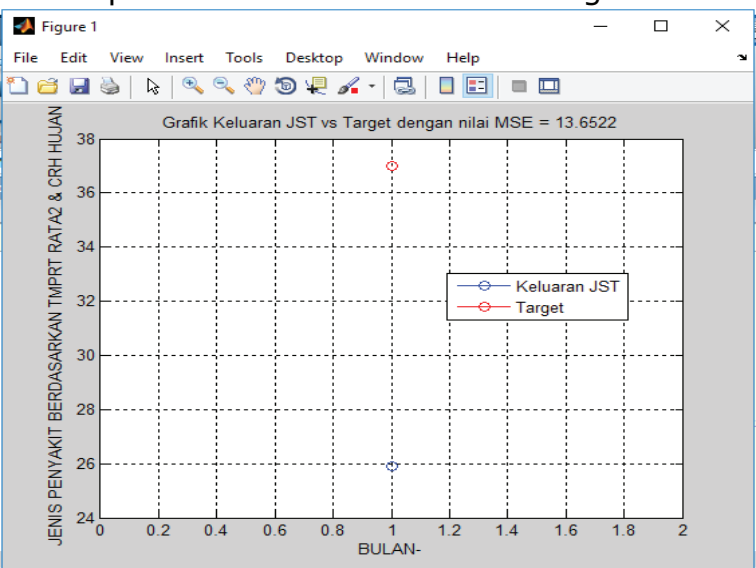

Figure 6 Example of Experimental Results Against Pharyngitis Disease in November 2020

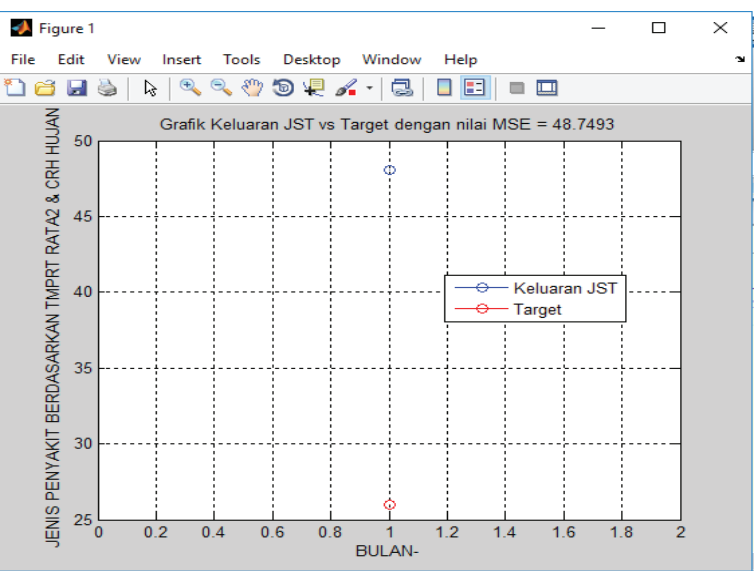

Figure 7 Example of Experimental Results Against Pharyngitis Disease in December 2020

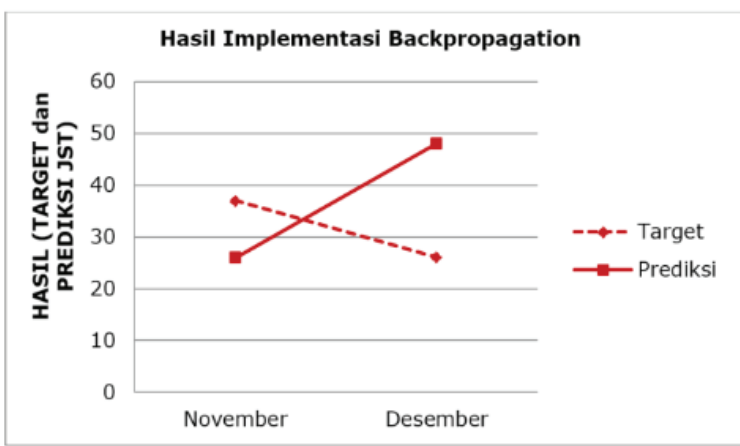

Figure 8 Results of Backpropagation Implementation

\subsection{Test Results}

In this study, we conduct 20 trials on each type of disease (pharyngitis/sore throat and dermatitis/itching) for November and December 2020. To find out how many patients had pharyngitis in November 2020, the training data used are from January to October 2020. Then to 
predict December 2020, the training data used is data from January to November 2020. This process is also carried out on dermatitis. The results of the trial of the type of pharyngitis/strep throat can be seen in Table 6 by including the target value $(T)$, prediction $(P)$ or output generated by the backpropagation artificial neural network, and the difference $(\mathrm{S})$ from the comparison between the target value and the predicted value. To find the difference $(S)$ is done by using calculations in Microsoft Excel, namely the absolute target value $(T)$ minus the absolute prediction value $(P)$. The results of the trial of the type of dermatitis/ itching disease can be seen in Table 7.

Table 6 Trial Results on Types of Pharyngitis/ Throat Disease

\begin{tabular}{|c|c|c|c|c|c|c|}
\hline \multirow{2}{*}{$\begin{array}{c}\text { Eksperiment } \\
\text { ke- }\end{array}$} & \multicolumn{3}{|c|}{ November } & \multicolumn{3}{c|}{ Desember } \\
\cline { 2 - 7 } & $\mathbf{T}$ & $\mathbf{P}$ & $\mathbf{S}$ & $\mathbf{T}$ & $\mathbf{P}$ & $\mathbf{S}$ \\
\hline 1 & 37 & 25.9153 & 11.0847 & 26 & 48.0792 & 22.0792 \\
\hline 2 & 37 & 24.1864 & 12.8136 & 26 & 34.9558 & 8.9558 \\
\hline 3 & 37 & 27.1080 & 9.8920 & 26 & 39.2020 & 13.2020 \\
\hline 4 & 37 & 28.2777 & 8.7223 & 26 & 39.5590 & 13.5590 \\
\hline 5 & 37 & 23.7224 & 13.2776 & 26 & 37.3396 & 11.3396 \\
\hline 6 & 37 & 23.2006 & 13.7994 & 26 & 42.9846 & 16.9846 \\
\hline 7 & 37 & 22.7107 & 14.2893 & 26 & 40.0025 & 14.0025 \\
\hline 8 & 37 & 25.2044 & 11.7956 & 26 & 39.4115 & 13.4115 \\
\hline 9 & 37 & 29.2600 & 7.7400 & 26 & 38.6342 & 12.6342 \\
\hline 10 & 37 & 25.4049 & 11.5951 & 26 & 35.7402 & 9.7402 \\
\hline 11 & 37 & 33.3933 & 3.6067 & 26 & 42.0052 & 16.0052 \\
\hline 12 & 37 & 22.6722 & 14.3278 & 26 & 48.5215 & 22.5215 \\
\hline 13 & 37 & 23.6113 & 13.3887 & 26 & 35.0575 & 9.0575 \\
\hline 14 & 37 & 17.6090 & 19.3910 & 26 & 44.2524 & 18.2524 \\
\hline 15 & 37 & 26.0597 & 10.9403 & 26 & 35.5026 & 9.5026 \\
\hline 16 & 37 & 30.6538 & 6.3462 & 26 & 50.7214 & 24.7214 \\
\hline 17 & 37 & 25.1739 & 11.8261 & 26 & 36.2327 & 10.2327 \\
\hline 18 & 37 & 20.1751 & 16.8249 & 26 & 37.7013 & 1.7013 \\
\hline 19 & 37 & 32.1847 & 4.8153 & 26 & 49.6945 & 23.6945 \\
\hline 20 & 37 & 23.4956 & 13.5044 & 26 & 48.7874 & 22.7874 \\
\hline JUMLAH/RATA- & & & & & & \\
\hline RATA & 37 & 25.5009 & 11.4991 & 26 & 41.2193 & 15.2193 \\
\hline
\end{tabular}

Table 7 Trial Results on Types of Dermatitis/Itching

\begin{tabular}{|c|c|c|c|c|c|c|}
\hline \multirow{2}{*}{$\begin{array}{c}\text { Eksperiment } \\
\text { ke- }\end{array}$} & \multicolumn{3}{|c|}{ November } & \multicolumn{3}{c|}{ Desember } \\
\cline { 2 - 7 } & $\mathbf{T}$ & $\mathbf{P}$ & $\mathbf{S}$ & $\mathbf{T}$ & $\mathbf{P}$ & $\mathbf{S}$ \\
\hline 1 & 27 & 40.4389 & 13.4389 & 19 & 37.1607 & 18.1607 \\
\hline 2 & 27 & 33.7563 & 6.7563 & 19 & 53.2159 & 34.2159 \\
\hline 3 & 27 & 28.6609 & 1.6609 & 19 & 47.8314 & 28.8314 \\
\hline 4 & 27 & 36.5785 & 9.5785 & 19 & 36.7628 & 17.7628 \\
\hline 5 & 27 & 21.1410 & 5.8590 & 19 & 72.9316 & 53.9316 \\
\hline 6 & 27 & 23.9257 & 3.0743 & 19 & 46.3367 & 27.3367 \\
\hline 7 & 27 & 38.9218 & 11.9218 & 19 & 41.7236 & 22.7236 \\
\hline 8 & 27 & 40.3179 & 13.3179 & 19 & 60.5680 & 41.5680 \\
\hline 9 & 27 & 27.3211 & 0.3211 & 19 & 67.9235 & 48.9235 \\
\hline 10 & 27 & 27.8142 & 0.8142 & 19 & 68.6259 & 49.6259 \\
\hline 11 & 27 & 40.6239 & 13.6239 & 19 & 40.0439 & 21.0439 \\
\hline 12 & 27 & 43.0088 & 16.0088 & 19 & 52.3529 & 33.3529 \\
\hline 13 & 27 & 25.1436 & 1.8564 & 19 & 44.9660 & 25.9660 \\
\hline 14 & 27 & 16.5981 & 10.4019 & 19 & 39.8997 & 20.8997 \\
\hline 15 & 27 & 22.6818 & 4.3182 & 19 & 53.5556 & 34.5556 \\
\hline 16 & 27 & -5.8239 & 32.8239 & 19 & 57.1586 & 38.1586 \\
\hline 17 & 27 & 38.0822 & 11.0822 & 19 & 46.0267 & 27.0267 \\
\hline 18 & 27 & 27.9503 & 0.9503 & 19 & 28.8088 & 9.8088 \\
\hline 19 & 27 & 33.0148 & 6.0148 & 19 & 53.7180 & 34.7180 \\
\hline 20 & 27 & 34.3227 & 7.3227 & 19 & 50.8123 & 31.8123 \\
\hline JUMLAH/RATA- & 27 & 29.7239 & 8.5573 & 19 & 50.0211 & 31.0211 \\
\hline RATA & & & & & & \\
\hline
\end{tabular}

Then with the results of the 20 trials, the predicted output for each type of disease (pharyngitis/sore throat, and dermatitis/itching) every month (November and December 2020) is illustrated in Figure 9. This image is a graphic image including the target value and the average of the predicted results (ANN outputs) carried out for 20 trials for each type of disease. The target for pharyngitis in November 2020 is 37 people with an average prediction result of 25.50. While the target for pharyngitis in December 2020 was 26 people with an average prediction result of 41.22. Furthermore, the target for dermatitis in November 2020 are 27 people with an average prediction of 29.72, and for the target of dermatitis in December as many as 19 people with an average prediction of 50.02 .

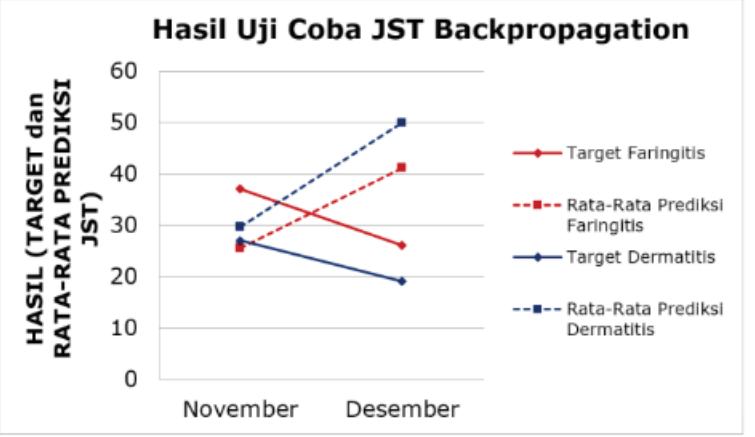

Figure 9 Average Trial Results Against Pharyngitis and Dermatitis Targets in November and December 2020

\subsection{Analysis and Conclusion}

After testing the model we make, we carry out the calculation of the percentage of precision. The precision percentage results are obtained from 20 trials on each type of disease every November and December 2020.

We divide the precision percentage results into 3 (three) conditions, namely the average precision percentage result, the best precision percentage result, and the worst precision percentage result from the 2nd (two) ) type of disease (pharyngitis / sore throat, dermatitis/ hives). The best percentage results are marked with a red circle and the worst percentage results with a blue circle. To obtain the three conditions of precision percentage results, look at Table 6 and Table 7. Then the calculation is carried out using the $100 \%$ formula - [[|Actual Data (Target) - Forecasting Results (Prediction)| : Actual Data (Target)] x 100].

The results of the percentage of precision obtained in the pharyngitis/laryngitis type experiment in November 2020 with an average precision is percentage of $68.92 \%$. The best percentage of precision is obtained in the 11 th experiment with a precision percentage of $90.25 \%$ and the worst percentage of precision in the 14th experiment of $47.59 \%$ which is illustrated in graphical form in Figure 10. 


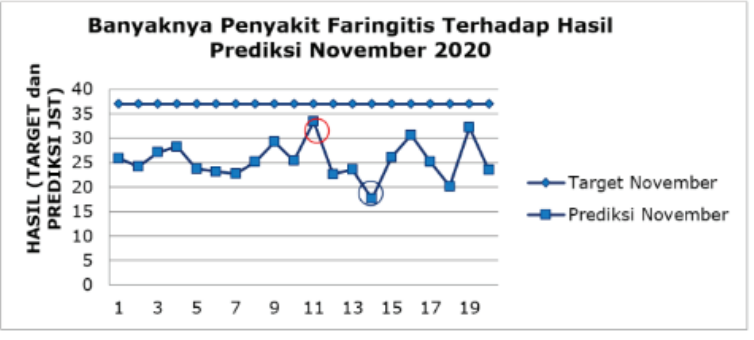

Figure 10 Pharyngitis Disease Trial Results in November 2020

In pharyngitis disease, in December 2020 the average precision percentage was $41.46 \%$, with the best precision percentage of $65.55 \%$ obtained in the 2nd experiment, and the worst precision percentage of $4.92 \%$ obtained in the 16th experiment can be seen in Figure 11.

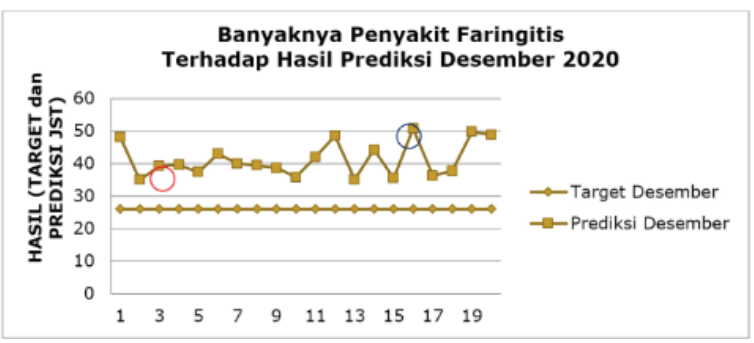

Figure 11 Pharyngitis Disease Trial Results in December 2020

Figure 12 is an image illustrated in graphic form for the type of Dermatitis/Itching in November 2020. The best percentage of precision is obtained in the 9th experiment with a precision percentage of $98.81 \%$, the average precision percentage of $68.31 \%$, and the worst precision percentage of $-21,57 \%$ in the 16 th experiment.

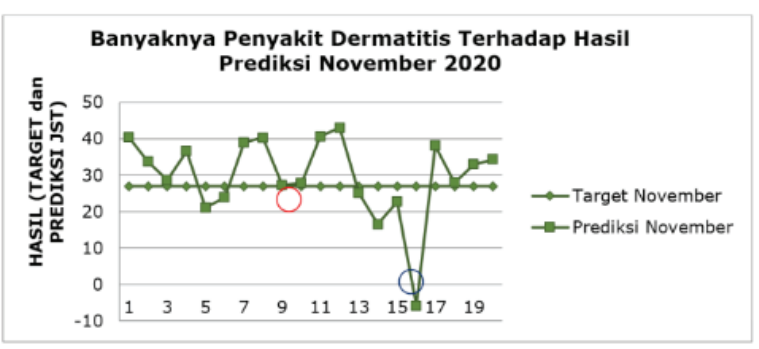

Figure 12 Darmatitis Disease Trial Results in November 2020

Dermatitis disease in December 2020 is illustrated in graphical form in Figure 13 with an average precision percentage of $-63.27 \%$. The best percentage of precision is obtained in the 18th experiment was $48.37 \%$ and the worst percentage of precision $-183.85 \%$ was obtained in the second experiment 5 .

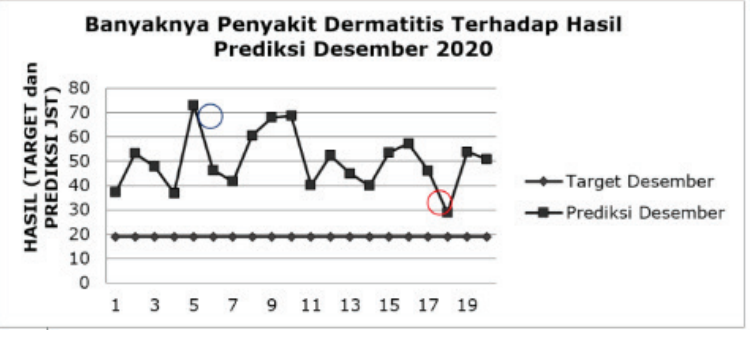

Figure 13 Trial Results of Darmatitis Disease in December 2020

By looking at the results of the trial of predicting the type of patient's disease based on the number of patients, the average temperature, and rainfall at the Az-Zainiyah clinic, we can see that backpropagation can predict the patient's disease well. Some experiments get a poor percentage of precision because the prediction results of the artificial neural network (ANN) are too low or too large to exceed the actual data target, it will have a large error value. However, if the prediction results from the ANN output are close to the actual target data, it will produce a good percentage of precision. In addition, there are data inputs in the form of many patients, and rainfall in one month with the following month experiencing drastic changes so that affect the training data.

\section{Closing}

Based on the results of the research that has been carried out, we can conclude that the backpropagation Artificial Neural Network (ANN) method can be applied properly to predict the number of patients for a type of disease at the Az-Zainiyah clinic based on data on the number of patients, average temperature and previous rainfall. The backpropagation algorithm can predict through several stages, namely, entering data on the number of patients for a disease (pharyngitis/sore throat, dermatitis/ itching), average temperature and rainfall, normalizing data, building backpropagation network architecture, determining the dataset to be used for $80 \%$ training data and $20 \%$ testing data, carrying out the training and data testing process, then simulating the results of the testing.

In this study, the backpropagation architecture used is 5-13-1 that we use 5 (five) parameters as variables that become signals as inputs. They consist of many patients last month (pharyngitis and dermatitis), the average temperature last month, next month's average temperature, 
last month's rainfall, next month's rainfall, 13 (thirteen) hidden layers, and 1 (one) parameter that produces an output signal variable, that is the number of patients next month (pharyngitis and dermatitis).

From the results of experiments carried out, we have different percentages of precision. Those are the average precision percentage, the best precision percentage, and the worst precision percentage. The results of the precision percentage in the pharyngitis/laryngitis type experiment in November 2020 with an average precision percentage is $68.92 \%$, the best precision is $90.25 \%$, and the worst precision is $47.59 \%$. In December 2020 the average precision percentage is $41.46 \%$, the best precision percentage is $65.55 \%$, and the worst precision percentage is $4.92 \%$. In the type of dermatitis/itching disease in November 2020 the best precision percentage was $98.81 \%$, the average precision percentage was $68.31 \%$, and the worst precision percentage was $-21,57 \%$. For December 2020 the average precision percentage is $-63.27 \%$, the best precision percentage is $48.37 \%$ and the worst precision percentage is $-183.85 \%$.

Some of the experiments that got the percentage of precision are not good. It is because the distance of the input data of the number of patients and the rainfall between the previous month and the following month which experienced change drastically. This greatly affects the prediction results of the artificial neural network (ANN) output. This results in a large difference or error value.

\section{References}

Andriyani, S., dan Sitohang, N. 2018. Implementasi Metode Backpropagation Untuk Prediksi Harga Jual Kelapa Sawit Berdasarkan Kualitas Buah. JURTEKSI Jurnal Teknologi dan Sistem Informas IV(2): 155-164.

Ashari, \& Muniar, A. Y. (2016). Implementasi Model Backpropagation Dan Forward Chaining Dalam Mendiagnosa Penyakit Pencernaan, Vol 6, No.02, Desember 2016

B. Rifai, "Algoritma Neural Network untuk Prediksi Penyakit Jantung," J. Techno Nusa Mandiri, vol. IX, no. 1, pp. 1-9, 2013.

Basariyadi, A. 2017. Definisi Penyakit dan Jenis Penyakit yang Mengancam Manusia. https:// majalah pendidikan.com/definisi-penyakitdan-jenis-penyakit-yang-mengancammanusia/ . 03 Maret 2019 (06:30).
Bayong Tjasyono, (2004). Klimatologi. ITB. Bandung.

Bustan M. (1997). Pengantar Epidemiologi. Rineka Cipta; Jakarta.

D. WULANDARI, (2011). Peramalan Rata-rata Temperatur Udara Harian Kota Pekanbaru menggunakan Model ARIMA.

Dewi, Candra., Muslikh, M. (2013). Perbandingan Akurasi Backpropagation Neural Network dan ANFIS untuk Memprediksi Cuaca. Program Studi Matematika Universitas Brawijaya. Malang

Ernyasih, (2018). Analisis Hubungan Iklim (Curah Hujan, Kelembaban, Suhu Udara dan Kecepatan Angin) dengan Kasus ISPA di DKI Jakarta Tahun 2011 - 2015, Jurnal Ilmu Kesehatan Masyarakat, Volume 07, Nomor : 03, September 2018, Jakarta.

F. Suhandi, Krisna. 2009. Prediksi Harga Saham Dengan Pendekatan Artificial Neural Network Menggunakan Algoritma Backpropagation, viewed 26 Agustus 2009, <http://krisnafebrianto.blog. upi.edu/2009 /06/27/prediksi-hargasaham-denganmenggunakan-pendekatan artificialneural-network-menggunakanalgoritmabackpropagation.html>.

Fausett, Laurene., 1994, Fundamentals of Neural Networks Architectures, Algorithms, and Applications, London: Prentice Hall, Inc.

H. Wadi, (2020). Jaringan Syaraf Tiruan Backpropagation Menggunakan Python GUI : Langkah demi langkah memahami dan mengimplementasikan jaringan syaraf tiruan Backpropagation untuk prediksi data penjualan air minum dalam kemasan. TR Publisher. Jakarta.

Heriyani, F. (2019). Correlation Between Air Temperature and Humidity. Berkala Kedokteran, 15(1), 1-6.

Kartasapoetra, A.G., 1986, Klimatologi Pengaruh Iklim Terhadap Tanah dan Tanaman, Jakarta: Bina Aksara.

Kusumadewi, Sri., 2003, Artificial Intelligence (Teknik dan Aplikasinya), Yogjakarta: Graha Ilmu.

Muh, A.R. 2017. Peramalan Komoditas Strategis Pertanian Cabai Menggunakan Metode Backpropagation Neural Network. Tugas Akhir. Fakultas Sistem Informasi FTIF Institut Teknologi Sepuluh Nopember. Surabaya.

Novi Indah Pradasari ,F.Trias Pontia W,Dedi Triyanto (2013) Aplikasi Jaringan Syaraf 
Tiruan Untuk Memprediksi Penyakit Saluran Pernafasan Dengan Metode Backpropagation, Jurnal Coding Sistem Komputer Universitas Tanjungpura pontiakan Vol 1, No 1 (2013).

P atel, Miss Ankeeta R., Joshi, Maulin M. 2013. Heart diseases diagnosis using Neural Network. EC Departement. India.

Paramita RM, Mukono J. (2018). Hubungan Kelembapan Udara dan Curah Hujan Dengan Kejadian Demam Berdarah Dengue Di Puskesmas Gunung Anyar 2010-2016. Indones J Public Heal. 2018;12(2):202. doi:10.20473/ijph.v12i2.2017.202-212.

Patel, Miss Ankeeta R., Joshi, Maulin M. (2013). Heart diseases diagnosis using Neural Network. EC Departement. India.

Psychologymania. 2012. Pengertian Curah Hujan. https://www.psychologymania. com/2013/05/pengertian-curah-hujan. html. 11 Maret 2019 (14:02).

Regariana, C. M. (2005). Atmosfer (Cuaca dan Iklim). Tiga Serangkai, Solo.
Stasiun Klimatologi Darmaga Bogor. (2012). Analisis Hujan dan Indeks Kekeringan Bulan November 2012 dan Prakiraan Hujan Bulan Januari, Februari dan Maret 2013.

Surakusumah W. (2011) Adaptasi dan Mitigasi. Bandung.

Susanti, N. 2014. Penerapan Model Neural Network Backpropagation Untuk Prediksi Harga Ayam. Prosiding SNATIF 2014, Universitas Muria Kudus: 325-332.

Suyanto. 2011.Artificial Intelligence, Revisi ed. Bandung: Informatika

Tjasyono, Bayong., 2004, Klimatologi, Bandung: ITB.

Trimulya, A., Syaifurrahman, dan Setyaningsih, F.A. 2015. Implementasi Jaringan Syaraf Tiruan Metode Backpropagation Untuk Memprediksi Harga Saham. Jurnal Coding Sistem Komputer Untan 03(2): 66-75. 